\title{
First record of the glass octopus Vitreledonella richardi (Cephalopoda: Vitreledonellidae) from the Arabian Sea
}

\author{
K. K. Sajikumar ${ }^{*}$, V. Venkatesan, R. Jeyabaskaran, Abbas Muhammed and K. S. Mohamed
}

\begin{abstract}
Background: Arabian Sea considered as one of the richest region of oceanic cephalopods. On conflicting information related to species diversity is still scare.

Result: This work presents the first report of a paralarvae of glass octopus Vitreledonella richardi from the Arabian Sea. A single specimen was collected during dusk by Isaacs-Kidd midwater trawl net on 28 February 2015. (Horizon of $150 \mathrm{~m}$ at $09^{\circ} 52^{\prime} 30^{\prime \prime} \mathrm{N} ; 73^{\circ} 37^{\prime} 22^{\prime \prime} \mathrm{E}$, bottom depth: $2005 \mathrm{~m}$ ). A description of the specimen is provided.
\end{abstract}

Conclusion: Record of this rare squid, from Arabian Sea is an addition to the cephalopod fauna of India.

Keywords: Vitreledonella richardi, Arabian Sea, Lower beak, Glass octopus

\section{Background}

Vitreledonella richardi Joubin 1918, also known as the glass octopus, is an incirrate octopus inhabiting mesobathypelagic waters of tropical and subtropical regions worldwide (Norman and Finn 2014). It attains mantle length (ML) up to $11 \mathrm{~cm}$ and a total length of up to $45 \mathrm{~cm}$. Vitreledonella richardi is the only representative of the genus Vitreledonella and of the family Vitreledonellidae (Norman and Finn 2014). The records of specimens identified as Vitriledonella are extremely rare and only few exist to the date (Norman and Finn 2014), mostly obtained from stomachs of predators (Santos et al. 2001; Galván-Magaña et al. 2013). In spite of more than 4000 planktonic hauls carried out in Arabian Sea and waters of India (Silas 1968; Aravindakshan and Sakthivel 1973; Piatkowski and Welsch 1991; Piatkowski et al. 1993; Chesalin and Zuyev 2002; Sajikumar et al. 2014) the species was never recorded there, and the nearest known record was south of Sri Lanka ( $78^{\circ} 30^{\prime \prime}$ E; 04 $20^{\prime \prime}$ N, Fig. 1) (Thore 1949). The present report provides information on the first record of the species in the Arabian Sea.

\section{Methods}

Zooplankton samples were collected at two stations during the research cruise of the F.V.Silver Pompano in February 2015, The Isaacs-Kidd midwater trawl (Model: IK-02.5 M-A1-00, Open Sea Instrumentation, Canada) was towed horizontally for $30 \mathrm{~min}$ at $150 \mathrm{~m}$ depth across Deep Scattering Layer (DSL) area. The specimen was collected at $10^{\circ} 30^{\prime} 22^{\prime \prime} \mathrm{N} 73^{\circ} 58^{\prime} 43^{\prime \prime} \mathrm{E}$.

Oceanographic parameters (sea surface temperature (SST), salinity and $\mathrm{pH}$ ) were measured with a YSI Multiparameter sonde (Model 650 MDS). The DSL was detected with an Echosounder Garmin-4210. Samples were preserved in $5 \%$ neutral buffered formalin. Sorting and identification were performed in the laboratory. Photographs and measurements were taken with a Nikon stereozoom microscope (SMZ-25). All measurement were done according Roper and Voss (1983) within $0.1 \mathrm{~mm}$. The specimen of $V$. richardi is housed in the collection of cephalopod in the Marine Biodiversity Museum of Central Marine Fisheries Research Institute (CMFRI), in Kerala, India (Accession number DE.03.01.02.07).

\section{Material examined}

On the 28 February 2015 at 1900 h, a single paralarvae of $V$. richardi (Fig. 2) was collected from a depth of $150 \mathrm{~m}$ near the Laccadive archipelago (Kalpeni Island, $09^{\circ} 52^{\prime}$ $\left.30^{\prime \prime} \mathrm{N} 73^{\circ} 37^{\prime} 22^{\prime \prime} \mathrm{E}\right)$, in the Arabian Sea. The maximum 

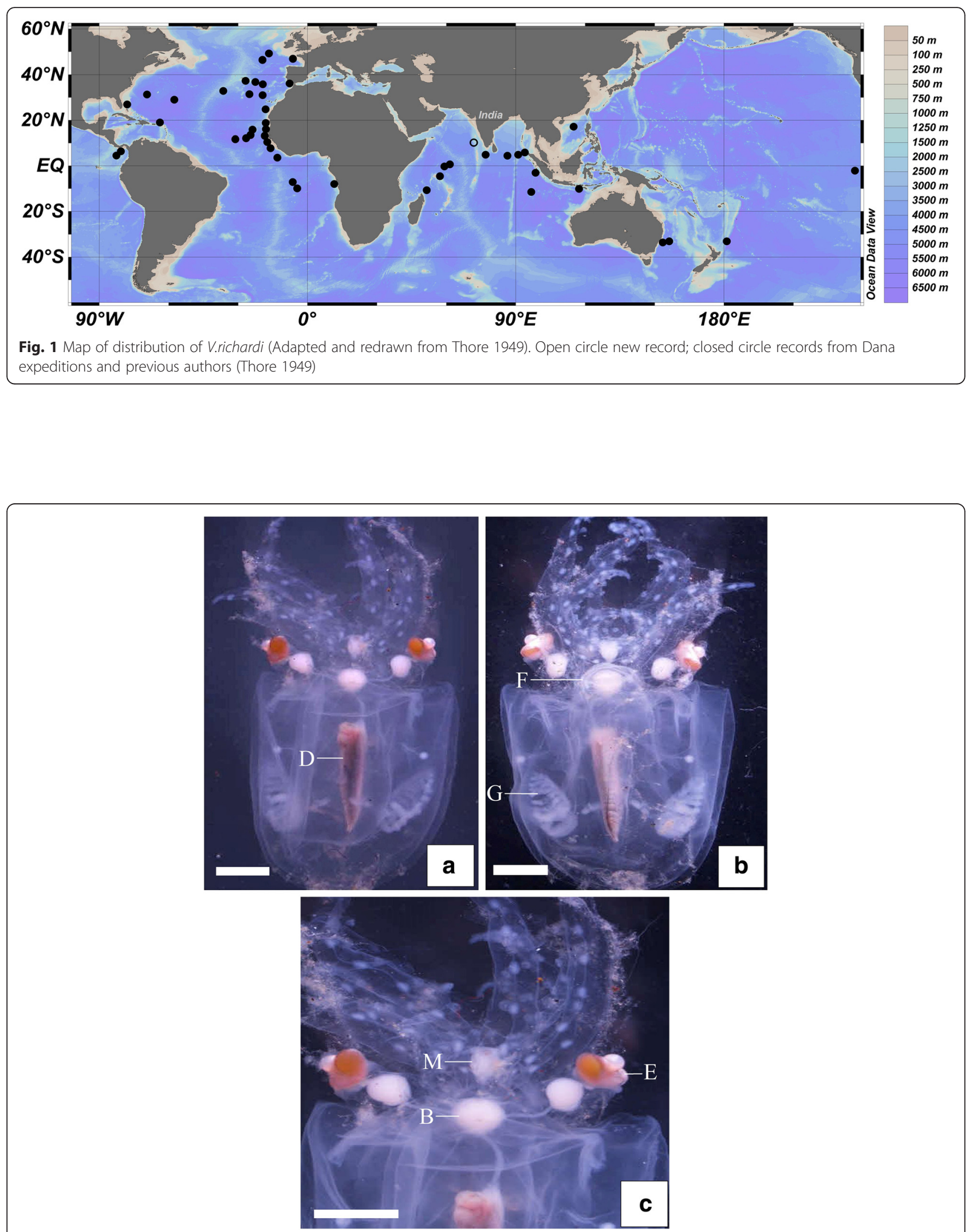

Fig. 2 Paralarva of Vitriledonella richardi a Dorsal and $\mathbf{b}$ ventral views (scale $=2 \mathrm{~mm}$ ) and $\mathbf{c}$ dorsal view of head. Organs indicating the funnel $(\mathrm{F})$, gill $(G)$, digestive systems $(D)$, mouth $(M)$, brain $(B)$ and Eye $(E)$ 
depth at the location was $2005 \mathrm{~m}$. The hydrographical data from the station are shown on Table 1 . The specimen was in good condition, although one eye was separated from the head. The specimen was identified based on Thore (1949) and Norman and Finn (2014).

\section{Results}

The specimen had a ML of $10.6 \mathrm{~mm}$. External morphological features of this paralarvae agree well with Thore (1949) and Norman and Finn (2014). The body was gelatinous and transparent. The mantle - elongate, oval in cross-section and rounded at the posterior end. The head was small, narrow, fused with mantle, and had no clear division from the arms (Fig. 2). The eyes were small, rectangular, with laterally directed lens (Fig. 3). Optic lobes of brain broadly spaced $(\sim 2 \mathrm{~mm})$ with elongated optic nerve stalks (Fig. 2c). The funnel was of moderate length, reached posterior margin the eye, and was not fused with head. Arms I-III were sub-equal in length and about as long as the mantle, while the arm pair IV was shorter. The arm formula was I $>$ II $>$ III $>$ IV (Fig. 2, Additional file 1). The suckers were small, widely separated, and in a single row. The digestive gland was long, slender, cigar-shaped and pointed at the posterior end; with the stomach located dorsal to it. The beak was different from that of an adult animal as the lower jaw bore 30 teeth like small projections (Fig. 4b) which is characteristic of a paralarvae. The lower jaw had a slit in the middle of rostrum (Fig. 4b). Both upper and lower jaws were poorly chitinised. The upper beak without projections or teeth.

\section{Discussion}

Vitreledonella richardi is considered to be one of the least studied cephalopods with circumglobal distribution. Thore (1949) indicated that this species occurs mostly near islands and sea mounts and nothing was found in the Arabian Sea.

The present record is the first from the Arabian Sea and was captured about 378 nautical miles from the closest record. The beak of adult V.richardi has been described by Young et al. (2015). The lower jaw structures of adults and paralarvae are very different: paralarvae have numerous teeth, whereas the lower jaw of the adult has a smooth rostrum (Fig. 4a) (Young et al., 2015). Such teeth have been observed also in paralarvae of other cephalopod

Table 1 Hydrographical data from the sampling location in southeastern Arabian Sea

\begin{tabular}{ll}
\hline Hydrographic parameters & Value \\
\hline Sea surface temperature (SST) & $29.21^{\circ} \mathrm{C}$ \\
Salinity & $34.9 \mathrm{ppt}$ \\
$\mathrm{pH}$ & 7.46 \\
\hline
\end{tabular}

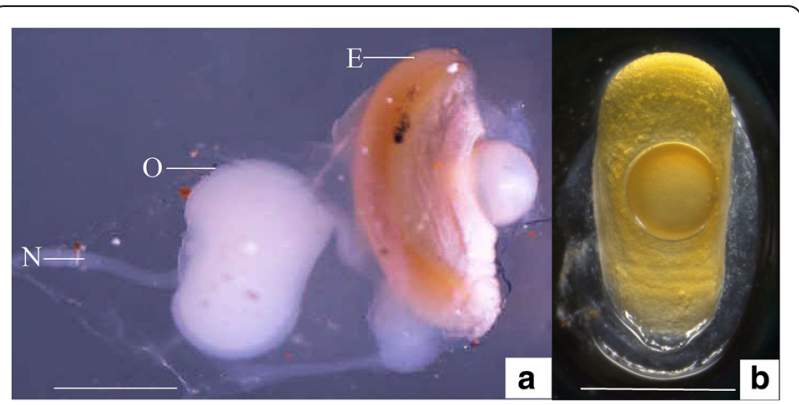

Fig. 3 Vitriledonella richardi rectangular shaped eye (side view) (a); eye $(\mathrm{E})$ with optic lobe $(\mathrm{O})$, optic nerve $(\mathrm{N})$ and front view of rectangular shaped eye $(\mathbf{b})($ Scale bar $=1 \mathrm{~mm})$

species (Boletzky 1974; Young et al. 1985; Wakabayashi et al. 2002; Franco-Santos and Vidal 2014). Experimental studies on paralarvae of O.vulgaris (Hernandez-Garcia et al. 2000) showed that they carry out external digestion and ingest the flesh only. The function of teeth at paralarval stage may be related to an adaptation facilitating the suction of the internal fluids of prey (Boletzky 1974; Franco-Santos and Vidal 2014) and removal of semidigested prey meat from exoskeleton as reported in adult Idiosepius paradoxus (Kasugai et al. 2004). At subsequent development of beaks these teeth disappear allowing crushing of hard parts of crustacean prey due to the shift in diet (Franco-Santos and Vidal 2014). Although there is no currently available information on the diet of early stages of V.richardi, their faint and less developed beak could perhaps be a sign of a diet on soft-bodied prey (Franco-Santos and Vidal 2014). The slit has also been observed in several other cephalopod paralarvae (Franco-Santos and Vidal 2014; Franco-Santos et al. 2014).

Different life stages of $V$. richardi seem to inhabit different depths in the water column. Adults are usually found in the meso - bathy pelagic zone, depths below $1000 \mathrm{~m}$ (Thore 1949). Recently hatched paralarvae were caught during the day in the North Atlantic between 310 and $400 \mathrm{~m}$ while larger specimens (3.5-11.5 mm ML) were caught between 110 and $300 \mathrm{~m}$ (Lu and Clarke 1975). The V.richardi belongs to cephalopods with so called $4^{\text {th }}$ type of ontogenetic vertical migrations particular for bathypelagic species

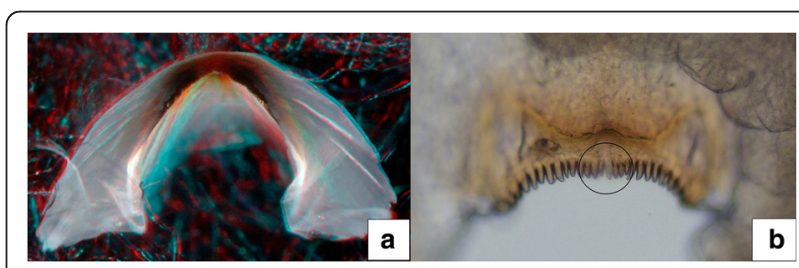

Fig. 4 a Lower jaw of a male Vitriledonella richardi with $90 \mathrm{~mm} \mathrm{ML}$ from Hawaiian waters (Photograph by R.E. Young). b Lower jaw (with 30 teeth) and slit on the rostrum (circled) of the specimen recorded in the present study 
like Japetella, Eledonella, Vitreledonella. Adult octopuses of these genera spawn in deep seas whereas paralarvae are widely distributed between $100 \mathrm{~m}$ and $>1000 \mathrm{~m}$ with larger paralarvae gradually getting closer to subsurface layers. Upon attaining particular size these octopods gradually move further from oceanic surface (Nesis 1985). Our finding is in agreement with this migratory pattern.

\section{Additional file}

Additional file 1: Morphometric measurement and indices (ML \%) of the Vitreledonella richardi paralarva from Arabian Sea. (XLSX $10 \mathrm{~kb}$ )

\section{Abbreviations}

DSL, deep scattering layer; $M L$, mantle length

\section{Acknowledgements}

We wish to acknowledge Dr. R.E. Young, University of Hawaii, for help with the identification of the specimen and valuable advice. We thank anonymous reviewers for critical comments which helped improve the manuscript. We are also grateful to the Director of the CMFRI, Kochi for facilities and to the captain and crew of F. V. Silver Pompano for their help with on-board sampling.

\section{Authors' contributions}

KKS carried out the sample collection carried out the identification and drafted the MS. W, AM and RJ participated in the cruise and helped to taking measurements and photographs. KSM designed and coordinated the study and corrected the draft manuscript. All authors read and approved the final manuscript.

\section{Authors' information}

KKS is technical assistant in CMFRI, Kochi. W and RJ are senior scientists in CMFRI, AM is a technician in CMFRI and KSM is a principal scientist and head of the Molluscan Fisheries Division of CMFRI.

\section{Competing interests}

The authors declare that they have no competing interests.

Received: 24 May 2016 Accepted: 3 June 2016

Published online: 11 July 2016

\section{References}

Aravindakshan PN, Sakthivel M. The location of cephalopod nurseries in the Indian Ocean. Handbook to the International Zooplankton Collections, Indian Ocean Biological Centre. 1973;5:70-5

Boletzky SV. The "larvae" of Cephalopoda: a review. Thalass Jugosl. 1974;10:45-76.

Chesalin MV, Zuyev GV. Pelagic cephalopods of the Arabian Sea with an emphasis on Sthenoteuthis oualaniensis. Bull Mar Sci. 2002;71:209-21.

Franco-Santos RM, Vidal EAG. Beak development of early squid paralarvae (Cephalopoda: Teuthoidea) may reflect an adaptation to a specialized feeding mode. Hydrobiologia. 2014;725:85-103.

Franco-Santos RM, Iglesias J, Domingues PM, Vidal EAG. Early beak development in Argonuta nodosa and Octopus vulgaris (Cephalopoda: Incirrata) paralarvae suggests adaptation to different feeding mechanisms. Hydrobiologia. 2014; 725:69-83.

Galván-Magaña F, Polo-Silva C, Aguilar-Castro NAS, Sandoval- Londoño A Castañeda-Suárez D, Chávez-Costa AC, Hernández-Aguilar SB, Ochoa-Diaz MR, Baigorrí-Santacruz A, Abitia-Cárdenas LA. Predation on cephalopods by sharks in the Mexican and Ecuadorian Pacific Ocean. Deep-Sea Res II Top Stud Oceanogr. 2013;95:52-62.

Hernandez-Garcia V, Martin AM, Castro JJ. Evidence of external digestion of crustaceans in Octopus vulgaris paralarvae. J Mar Biol Assoc UK. 2000;80: 559-60.

Joubin L. Etudes preliminaires sur les cephalopodes recueillis au cours des croisieres de SA.S. le Prince de Monaco, 6e Note: Vitreledonella richardi Joubin. Bull Inst Océanogr Monaco. 1918;340:1-40.
Kasugai T, Shigeno S, Ikeda Y. Feeding and external digestion in the Japanese pigmy squid Idiosepius paradoxus (Cephalopoda: Idiosepiidae). J Molluscan Stud. 2004;70:231-6.

Lu CC, Clarke MR. Vertical distribution of cephalopods at 11 N 20 W in the North Atlantic. J Mar Biol Assoc UK. 1975;55-2:369-89.

Nesis KN. Oceanic cephalopod molluscs. Moscow: Nauka (In Russian); 1985.

Norman MD, Finn JK. Family Vitreledonellidae in P. Jereb, CFE Roper, MD Norman and JK Finn, editors. Cephalopods of the world. An annotated and illustrated catalogue of Cephalopod species known to date, Octopods and Vampire squids. Rome: FAO species catalogue for fishery purposes 4; 2014;219-21.

Piatkowski U, Welsch W. On the distribution of pelagic cephalopods in the Arabian Sea. Bull Mar Sci. 1991;49:186-98.

Piatkowski U, Welsch W, Röpke A. Distribution patterns of the early life stages of pelagic cephalopods in three geographically different regions of the Arabian Sea. In: Okutani T, O'Dor RK, Kubodera T, editors. Recent Advances in Cephalopod Fisheries Biology. Tokyo: Tokai University Press; 1993. p. 417-31.

Roper CFE, Voss GL. Guidelines for taxonomic descriptions of cephalopod species. Natl Mus Victoria Mem. 1983;44:49-61.

Sajikumar KK, Ragesh N, Koya KPS, Venkatesan V, Joseph M, Remya R, Mohamed KS. Paralarva of the sharpear enope squid Ancistrocheirus lesueurii (Oegopsida: Ancistrocheiridae) in the southeastern Arabian Sea. J Mar Biol Assoc India. 2014:55-2:79-82

Santos MB, Pierce GJ, Reid RJ, Patterson IAP, Ross HM, Mente E. Stomach contents of bottlenose dolphins (Tursiops truncatus) in Scottish waters. J Mar Biol Assoc UK. 2001;81:873-8.

Silas EG. Cephalopoda of the west coast of India collected during the cruises of the research vessel Varuna, with a catalogue of the species known from the Indian Ocean. In: Virabhadra RK, editor. Proceedings of the Symposium on Mollusca held at Cochin from January 12 to 16 1968, Part - II, Marine Biological Association of India. Bangalore: The Bangalore Press; 1968. p. 277-359.

Thore S. Investigation on the "Dana" octopoda. Dana-Report. 1949;33:85.

Wakabayashi T, Saito K, Tsuchiya K, Segawa S. Descriptions of Eucleoteuthis luminosa (Sasaki, 1915) and Ornithoteuthis volatilis (Sasaki, 1915) paralarvae in the northwestern Pacific. Venus. 2002;60:237-60.

Young RE, Mangold K, Vecchione M. Vitreledonellidae Robson, 1932 Vitreledonella richardi Joubin, 1918 Verson 4 March 42015 (under construction). Tree of Life Web Project. 2015. http://tolweb.org/Vitreledonella_richardi/149589.

Young RE, Harman RF, Mangold KM. The eggs and larvae of Brachioteuthis sp. (Cephalopoda: Teuthoidea) from Hawaiian waters. Vie et Milieu. 1985;35:203-9.
Submit your next manuscript to BioMed Central and we will help you at every step:

- We accept pre-submission inquiries

- Our selector tool helps you to find the most relevant journal

- We provide round the clock customer support

- Convenient online submission

- Thorough peer review

- Inclusion in PubMed and all major indexing services

- Maximum visibility for your research

Submit your manuscript at www.biomedcentral.com/submit
BioMed Central 